\title{
Correction to: The Abecedarian Approach in a Low-Resource Urban Neighborhood in Canada: An Impact Evaluation in a Child Care Setting
}

\author{
Harvey Stevens ${ }^{1} \cdot$ Rob Santos $^{1,2} \cdot$ Shelley Jonasson $^{3}$ (D) Carolyn Young $^{4}$. \\ Sandy Mann ${ }^{4}$. Carly Sass ${ }^{4}$. Jan Sanderson ${ }^{5}$. Janet Jamieson ${ }^{5}$. \\ Melanie D'Souza ${ }^{5} \cdot$ Kimberly Meunier $^{6} \cdot$ Joseph Sparling ${ }^{6,7,8}$
}

Published online: 19 December 2019

(c) Springer Nature B.V. 2019

\section{Correction to: International Journal of Early Childhood (2019) 51(2):217-232 https://doi.org/10.1007/s13158-019-00245-4}

The article "The Abecedarian Approach in a Low-Resource Urban Neighborhood in Canada: An Impact Evaluation in a Child Care Setting", written by Harvey Stevens, Rob Santosa, Shelley Jonasson, Carolyn Young, Sandy Mann, Carly Sass, Jan Sanderson, Janet Jamieson, Melanie D’Souza, Kimberly Meunier, Joseph Sparling was originally published electronically on the publisher's internet portal (currently SpringerLink) on 3 August 2019 without open access.

With the author(s)' decision to opt for Open Choice, the copyright of the article changed on 19 December 2019 to (C) The Author(s) 2019 and the article is forthwith distributed under the terms of the Creative Commons Attribution 4.0 International License (http://creativecommons.org/licenses/by/4.0/), which permits use, duplication, adaptation, distribution and reproduction in any medium or format, as long as

The original article can be found online at https://doi.org/10.1007/s13158-019-00245-4.

Shelley Jonasson

shelley.jonasson@gov.mb.ca

1 University of Manitoba, Winnipeg, MB R3T 2N2, Canada

2 Government of Manitoba, 307-1181 Portage Avenue, Winnipeg, MB R3G 0T3, Canada

3 Healthy Child Manitoba Office, Government of Manitoba, 300-332 Bannatyne Avenue, Winnipeg, MB R3A 0E2, Canada

4 Manidoo Gi-Miini Gonaan, 102-269 Dufferin Avenue, Winnipeg, MB R2W 2X8, Canada

5 Red River College, A141-2055 Notre Dame Avenue, Winnipeg, MB R3H 0J9, Canada

6 Abecedarian Education Foundation, 2505 Bartlett Circle, Hillsborough, NC 27278, USA

7 University of Melbourne, Melbourne, Australia

8 University of North Carolina, Chapel Hill, USA 
you give appropriate credit to the original author(s) and the source, provide a link to the Creative Commons license and indicate if changes were made.

Publisher's Note Springer Nature remains neutral with regard to jurisdictional claims in published maps and institutional affiliations. 